\title{
Broiler farming: An approach to improve rural livelihood
}

\author{
L. Mozumdar, K. S. Farid, J. U. Ahmed ${ }^{1}$ and M. W. Rahman \\ Department of Rural Sociology, Bangladesh Agricultural University, Mymensingh-2202, Bangladesh and ${ }^{1}$ Department \\ of Agricultural Economics, Sylhet Agricultural University, Sylhet
}

\begin{abstract}
The present study assessed the changes in socio-economic conditions of small scale broiler farmers in rural areas of Bangladesh. The population comprised the small scale broiler farmers who reared at least 300 to less than 2000 birds in the rural areas of Sadar Upazila of Mymensingh district, among which a total of 50 samples were randomly selected for the study. The necessary data on different socio-economic parameters were collected from the respondents through personal interview with the pre-tested interview schedule. Findings showed that annual employment opportunities for unemployed family members of broiler farmers were 302.96 man-days. The overall income and expenditure of the farmers were increased by TK.6100 and TK.3064.66 after involving in broiler farming. Cash in hand and savings with bank raised by $142.71 \%$ and $201.63 \%$ respectively. Drinking water from own tubewell increased by $135.71 \%$ and katcha latrines decreased by $76.47 \%$. Consumption of meat, egg, and fruits per month per household were increased by $94.32 \%, 34.53 \%$ and $56.14 \%$ respectively in post farming situation. The number of school going children, household assets and health status also improved. So, small scale broiler farming has positive and significant impact for the development of socio-economic status of the farmers as well as the improvement of rural livelihood.
\end{abstract}

Keywords: Broiler farming, Rural livelihood, Socio-economic development

\section{Introduction}

Broiler farming plays an important role in improving livelihood, food security and poverty alleviation in rural and semi-urban communities in developing countries including Bangladesh. Broiler production has become a specialized and speedy business at present time for the people of the country. Short life cycle of the broiler and requirement of relatively less amount of capital attributed to its popularity to the farmers. A large number of energetic men and women are coming forward to undertake broiler farming as a means of self employment. Broiler farming has also been playing an important role in improving livelihoods of the farmers. There are some examples where the broiler raisers have changed their socioeconomic conditions to a considerable extent. A study report on the impact on Smallholder Livestock Development Project (SLDP) in rural community at different rural areas of Bangladesh revealed that the overall socio-economic condition of the beneficiaries, their egg and meat consumption capability, empowerment of rural women in decision making issues and employment opportunities were significantly increased after the intervention made by SLDP (Alam, 1997). Another study showed that commercial broiler farming provided employment opportunities for unemployed family members, improved socioeconomic conditions and increased women empowerment among rural people of Bangladesh (Rahman et al., 2006).

Broiler meat contains high quality protein and micro-nutrients which has had a tremendous impact on health and nutrition for the poor people in rural areas (Neumann et al., 2002; Barroetoa, 2007). Again, another study reported that it can be the main source of family earning or can provide sufficient income and gainful employment opportunity to rural farmers throughout the year (Bhende, 2006). For this reason, broiler farming has been playing a key role in providing meat to overcome the malnutrition and serve as a tool for employment generation and poverty alleviation (Raha, 2007). All these evidences suggested that commercial broiler farming deserve wider scale expansion throughout the country as a poverty reduction activity. Despite its high potential the broiler farming is not based on sound footings. Studies revealed that most of the broiler farm owners suffered from adequate amount of credit to run their farms and provision of credit for poultry farming is not yet very regular and well established practice among all the financial institutions - banks and NGOs in Bangladesh (Jabbar et al., 2005). So, broiler farm owners face various problems like shortage, high price and poor quality of DOC (Day-old chick); high price, poor quality and unavailability of feeds; high cost and low quality of medicine, vaccine and veterinary services; shortage of capital; inadequate marketing facilities; and poor transportation and communication (Raha, 2007). 
Though broiler farming faces various problems, a huge scope exists for development of broiler industry in Bangladesh. It is interesting to note that broiler farming is solely in the private sector particularly in the hands of small farmers who are running their enterprise through self-finance. So it is very much necessary to assess whether broiler farming is contributing positively for the socio-economic development of the broiler farmers or not. The overall objective of the present study is, however, to estimate and assess the extent of improving livelihood of small scale commercial broiler farmers. It also identifies and analyzes the problems faced by the farm holders.

\section{Materials and Methods}

In order to fulfill the objectives of the study Sadar Upazila of Mymensingh district was purposively selected due to the concentration of the broiler farm. In Mymensingh district small-scale broiler farming started its journey in around 1980 and since then number of farms were increasing. There was huge demand of broiler meat in Mymensingh district as there were many educational institutions, hotels and restaurants and hospitals. So, broiler farming was expanding day by day in Mymensingh. Another reason of selecting Mymensingh as the study area was that it was $121 \mathrm{~km}$ from Dhaka, the capital of Bangladesh, and well communicated by both road and train. Five Villages namely, Sutiakhali, Char Nillokhia, Sombu-gonge, Bailor and Tarakanda under Mymensingh district were randomly selected for the study. The small scale broiler farm owners were the population of the present study. The population comprised 126 broiler farmers (DLO, 2008) in the study area and a total of 50 samples were collected randomly. The present study was based on a set of field level primary data collected from the respondents. The data were collected during the period from January to April, 2009 in a regular basis by the researcher himself. The primary sources of data were a combination of quantitative and qualitative methods such as interview using structured and pre-tested interview schedule, Focus Group Discussion (FGD) and participant observation etc. After collecting requisite data, they were processed and analyzed with a view to achieve the objectives of the study. Data were edited and initially collected data in local units were converted into standard international units to improve their quality. Then the edited data were compiled, classified, tabulated and analyzed by using SPSS (Statistical Package for Social Sciences). For analysis and presentation of data different statistical tools like frequency distributions, percentages, ratios, mean, decision making index etc. were applied for quantitative data and for qualitative data other qualitative tools like weighted score and rank order were also used. In the process of ranking three priorities were sorted for specific item in order of importance by asking the respondents of this study, and after giving weight score ( 3 for priority I, 2 for priority II, 1 for priority III) to each of the three priorities, the final rank order was drawn. Tabular analyses of significant items were depicted through charts, graphs and diagrams etc. because of their simplicity to use and understand.

\section{Results and Discussions}

\section{Employment opportunity}

Small scale commercial broiler farming provided an annual employment opportunity to the family members of broiler farmers for 302.96 man-days (Table 1). Many authors in their studies observed that similar type of employment opportunities created for rural poor, landless laborers, small and marginal farmers and unemployed or under employed laborers (Sirohi, 1982; Mulla, 1995; Alam et al., 1998; Prodhan, 1995; Verma et al., 1998; Rahman et al., 2006). Thus, adopting of small scale broiler farming made a positive impact on the employment opportunities to the unemployed family labors in the study area.

Table 1. Employment opportunity of family members

\begin{tabular}{|l|c|c|c|}
\hline Categories & Working hours/day & Man-days & Annual Man-days \\
\hline Adult male & 4.75 & 0.59 & 216.72 \\
\hline Adult female & 1.32 & 0.17 & 60.23 \\
\hline Children & 0.57 & 0.07 & 26.01 \\
\hline Total & 6.64 & 0.83 & 302.96 \\
\hline
\end{tabular}

Source: Field Survey, 2009 


\section{Occupational status of the respondents}

From the Table 2, it is clear that the main occupation (from which the respondents earn large part of their income) of $34 \%$ respondents was broiler farming and the remaining $66 \%$ respondents involved with broiler farming as their secondary occupation. Among these $66 \%$ respondents, $4 \%$ involved with fisheries, $6 \%$ were business, $8 \%$ were service holders, and $2 \%$ involved with others occupation as their principal occupation.

Table 2. Occupational status of respondents

\begin{tabular}{|l|c|c|c|c|}
\hline \multirow{2}{*}{ Occupation } & \multicolumn{2}{|c|}{ Main } & \multicolumn{2}{c|}{ Subsidiary } \\
\cline { 2 - 5 } & No. of respondents & Percentage & No. of respondents & Percentage \\
\hline Broiler farming & 17 & 34.0 & 33 & 66.0 \\
\hline Crop production & 23 & 46.0 & 5 & 10.0 \\
\hline Fisheries & 2 & 4.0 & 4 & 8.00 \\
\hline Business & 3 & 6.0 & 7 & 14.0 \\
\hline Services & 4 & 8.0 & 1 & 2.0 \\
\hline Others & 1 & 2.0 & 0 & 0.0 \\
\hline Total & 50 & 100.0 & 50 & 100.00 \\
\hline
\end{tabular}

Source: Field Survey, 2009

\section{Monthly household income and expenditure}

The overall monthly income (calculated by deducting cost incurred for broiler farming from the total return) of the farmers increased from Tk. 6394.00 to Tk.12494.66, whereas the monthly income from broiler farming was Tk. 6028.00. Thus positive changes in household income occurred due to the adoption of small scale commercial broiler farming (Fig.1).The total household expenses of the respondents in compare to before and after (during the period of survey, i.e. in 2009) intervention through broiler farming was increased by Tk.3064.66. The increased income of the farmers influenced them to make more investment in broiler farming and spend more money in different aspects of household.

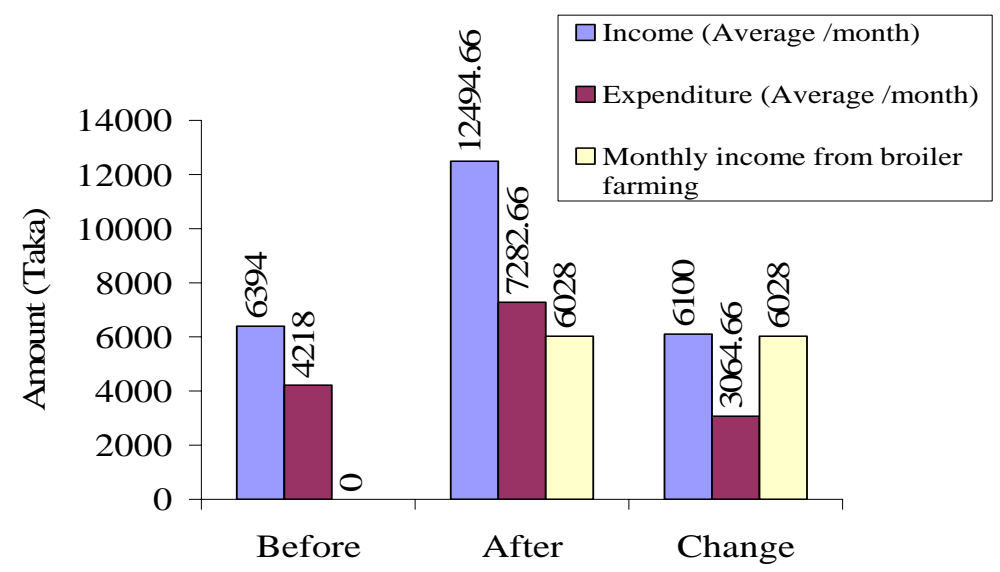

Time period

Fig. 1. Monthly total household income and expenditure pattern

\section{Current savings and investment}

The percentage change of cash in hand and savings with banks were increased by $142.71 \%$ and $201.63 \%$ respectively after the adoption of broiler farming. These changes were bearing a directing financial impact on investment in broiler business due to the adoption of small scale commercial broiler farming. 
Table 3. Current savings and investments pattern of respondents

\begin{tabular}{|l|c|c|c|}
\hline \multirow{2}{*}{ Particulars } & \multicolumn{3}{|c|}{ Mean size } \\
\cline { 2 - 4 } & Investment in broiler business & Cash in hand & Savings with bank \\
\hline Before & 0.00 & 10620.00 & 1470.00 \\
\hline After & 122380.00 & 25776.00 & 4434.00 \\
\hline$\%$ change & $\infty$ & 142.71 & 201.63 \\
\hline
\end{tabular}

Source: Field Survey, 2009

\section{Conditions of school-going children}

School-going boys and girls of broiler farmers were increased by $52.54 \%$ and $54.43 \%$ respectively. Most of the respondents expressed that the education expenses of their children were increased which was affordable with their increased income from broiler farming.

Table 4. Distribution of students by institute

\begin{tabular}{|l|c|c|c|c|c|c|}
\hline \multirow{2}{*}{ Particulars } & \multicolumn{3}{|c|}{ Average no. of Boy } & \multicolumn{3}{c|}{ Average no. of Girl } \\
\cline { 2 - 3 } & Before & After & \%change & Before & After & \%change \\
\hline Primary & 0.52 & 0.63 & 21.15 & 0.27 & 0.50 & 85.19 \\
\hline High school & 0.49 & 0.72 & 46.94 & 0.34 & 0.46 & 35.29 \\
\hline College & 0.14 & 0.21 & 50.00 & 0.16 & 0.23 & 43.75 \\
\hline University & 0.03 & 0.04 & 33.33 & 0.02 & 0.03 & 50.00 \\
\hline Total & 1.18 & 1.80 & 52.54 & 0.79 & 1.22 & 54.43 \\
\hline
\end{tabular}

Source: Field Survey, 2009

\section{Changes in possession of household assets}

The increased income of the respondents through participation of broiler farming also reflected in the possession of household assets. Family assets like television, sewing machine, dining table, electric fans and mobile phone were increased by $170.00 \%, 87.87 \%, 109.09 \%, 84.29 \%$ and $78.72 \%$ respectively after adopting broiler farming. Table 5 also reveled that on the basis of number of respondents, ownership of household assets of the broiler farmers were also found an increasing trend. All these changes in household assets implied that small scale broiler farming has a direct effect on purchasing capacity of the respective households. It is evident and expected that there was no family, the assets of that decreased after the involvement of broiler farming. Almost all of the items of household assets were increased in variety of extent.

Table 5. Households assets of respondents

\begin{tabular}{|l|c|c|c|c|c|c|}
\hline \multirow{2}{*}{ Assets } & \multicolumn{3}{|c|}{ Mean size } & \multicolumn{3}{c|}{ No. of respondents } \\
\cline { 2 - 7 } & Before & After & \% change & Before & After & \% change \\
\hline Chauki/ khat & 2.35 & 3.27 & 39.15 & 47 & 50 & 6.38 \\
\hline Chair and table & 3.99 & 6.74 & 68.92 & 48 & 50 & 4.17 \\
\hline Almira & 0.69 & 1.00 & 44.92 & 37 & 44 & 18.91 \\
\hline Alna & 0.82 & 1.30 & 58.54 & 29 & 47 & 62.21 \\
\hline Bi-cycle & 0.78 & 1.48 & 89.74 & 37 & 48 & 29.72 \\
\hline Sewing machine & 0.33 & 0.62 & 87.87 & 17 & 32 & 88.24 \\
\hline Dining table & 0.22 & 0.46 & 109.09 & 11 & 27 & 145.45 \\
\hline Electric fans & 1.21 & 2.23 & 84.29 & 27 & 50 & 85.19 \\
\hline DVD player & 0.68 & 1.16 & 70.59 & 34 & 49 & 44.12 \\
\hline Television & 0.40 & 1.08 & 170.00 & 25 & 42 & 68.00 \\
\hline Mobile phone & 0.47 & 0.84 & 78.72 & 19 & 50 & 163.00 \\
\hline
\end{tabular}

Source: Field Survey, 2009 


\section{Sources of drinking water and latrine condition}

The sources of drinking water from own tube-well and shared in deep tube-well were increased by 135.71 and 80.00 percent respectively and shared in tube-well decreased by 74.19 percent after the involvement of broiler farming than before. Thus, broiler farming created a positive impact on the sources of drinking water of the broiler farmer. After broiler farming, ownership of katcha latrines were decreased by 76.47 percent but ownership of sanitary latrines were increased by 33.33 percent. It indicates that broiler farming has made an encouraging intervention on sanitation of broiler farmers.

Table 6. Sources of drinking water and condition of latrines

\begin{tabular}{|l|c|c|c|}
\hline \multirow{2}{*}{ Particulars } & \multicolumn{2}{|c|}{ No. of respondents } & \multirow{2}{*}{ \% change } \\
\cline { 2 - 4 } & \multicolumn{3}{|c|}{ Before } \\
\hline Sources of drinking water \\
\hline Own tube-well & 14 & 33 & 135.71 \\
\hline Shared-in tube-well & 31 & 8 & -74.19 \\
\hline Shared-in deep tube-well & 5 & 9 & 80.00 \\
\hline Latrine condition & 17 & 4 & -76.47 \\
\hline Katcha & 27 & 38 & 40.74 \\
\hline Semi-sanitary & 6 & 8 & 33.33 \\
\hline Sanitary & \multicolumn{3}{|c|}{} \\
\hline
\end{tabular}

Source: Field Survey, 2009

\section{Consumption patterns of the respondents' household}

Table 7 represents that all types of consumption increased to a certain extent after the involvement of broiler farming. The average meal consumed per day by the sample households increased from 2.34 times to 2.85 times between before and after periods. On an average the sample households consumed about 7.19 kilograms meat per month after the involvement in broiler farming which was about 3.70 kilograms before involvement. Again, consumption of meat, egg, and fruits per month per household were increased by $94.32 \%, 34.53 \%$ and $56.14 \%$ after the initiation of broiler farming than before. It is obvious that some sorts of changes might be occurred in consumption patterns of the respondents' household after their connection with it. Quality and quantity of food intake of the farmers were found to be changed positively after adopting broiler farming and therefore, food and nutritional status of the farmers' household were improved to some extent.

Table 7. Changes in consumption patterns per household

\begin{tabular}{|l|c|c|c|}
\hline \multirow{2}{*}{ Particulars } & \multicolumn{2}{|c|}{ Household Consumption (Mean) } & \multirow{2}{*}{ Percentage Change } \\
\cline { 2 - 3 } & Before & After & \\
\hline Meals per day (times) & 2.34 & 2.85 & 21.79 \\
\hline Fish per month (kg.) & 8.32 & 9.23 & 10.93 \\
\hline Meat per month (kg.) & 3.70 & 7.19 & 94.32 \\
\hline Milk per month (liter) & 6.65 & 7.78 & 16.99 \\
\hline Egg per month (no.) & 12.48 & 16.79 & 34.53 \\
\hline Vegetables per month (kg.) & 10.99 & 12.94 & 17.74 \\
\hline Fruits per month (kg.) & 3.58 & 5.59 & 56.14 \\
\hline
\end{tabular}

Source: Field Survey, 2009

\section{Health status of respondents}

Fifty four percent of broiler farmers reported that their family health status was improved. They further opined that the occurrences of diseases were reduced by $56 \%$ and annual cost for treatment was supported by $66 \%$ after conducting broiler farming (Fig. 2). 


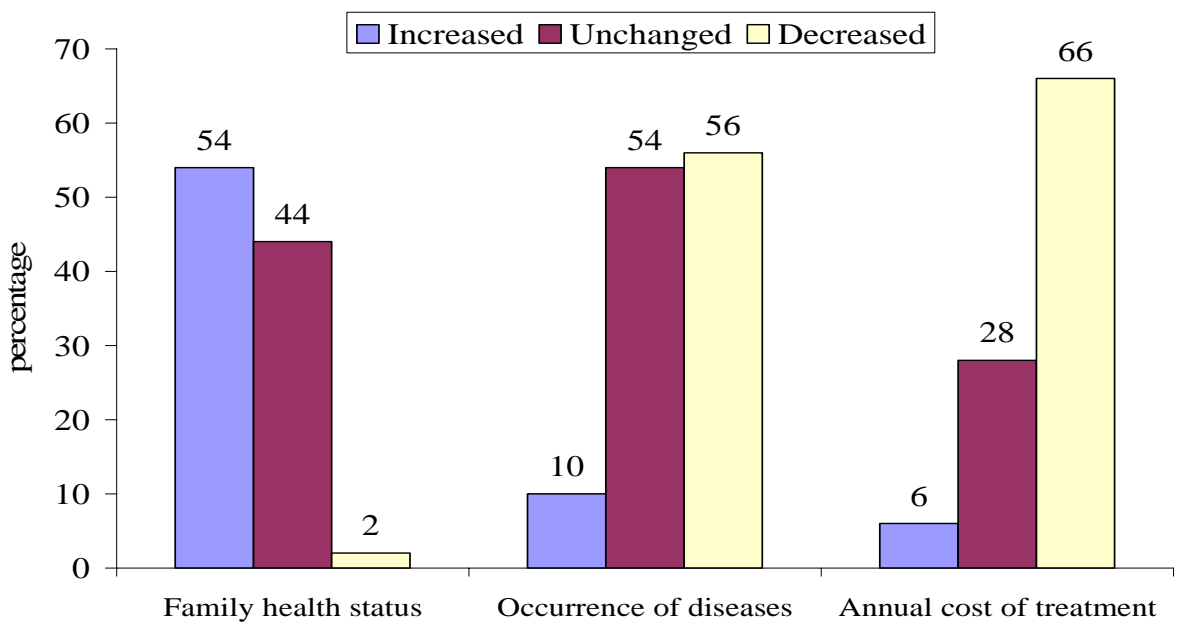

Health Status

Fig. 2. Health status of respondents

\section{Problem faced by the broiler farmers}

There were several problems faced by the broiler farmers. An attempt was taken to determine the most pertinent problems in this regard. From the Table 8 it is found that the first and foremost problem faced by the farmers was 'too much fluctuation of DOC (Day Old Chick) and feed price'. The second and third important problems were 'high cost of medication and vaccination and their low quality' and 'high fluctuation of broiler price' respectively.

Table 8. Problems faced by the broiler farmers

\begin{tabular}{|c|c|c|c|c|c|}
\hline \multirow[b]{2}{*}{ Problems } & \multicolumn{3}{|c|}{ Priorities } & \multirow{2}{*}{$\begin{array}{c}\text { Total } \\
\text { weighted } \\
\text { score }\end{array}$} & \multirow{2}{*}{$\begin{array}{l}\text { Final } \\
\text { Rank } \\
\text { order }\end{array}$} \\
\hline & I & II & III & & \\
\hline Too much fluctuation of DOC and feed price & 15 & 9 & 6 & 69 & $\mathrm{I}$ \\
\hline Medication and vaccination cost is high and low quality & 7 & 12 & 4 & 49 & II \\
\hline Inadequate Veterinary services & 2 & 1 & 3 & 11 & VIII \\
\hline Shortage of capital & 3 & 6 & 8 & 29 & $\mathrm{~V}$ \\
\hline Uncertainty of electricity supply & 2 & 3 & 5 & 17 & VII \\
\hline High fluctuation of broiler price & 9 & 5 & 4 & 41 & III \\
\hline Disorganized marketing system & 4 & 3 & 6 & 24 & $\mathrm{VI}$ \\
\hline Lack of training facilities & 6 & 5 & 5 & 33 & IV \\
\hline Poor quality and high mortality rate of DOC & 1 & 2 & 2 & 9 & $\mathrm{X}$ \\
\hline Transportation problem & 1 & 2 & 3 & 10 & IX \\
\hline $\begin{array}{l}\text { Others (Lack of marketing information, shortage of broiler DOC, } \\
\text { Poor quality feeds etc) }\end{array}$ & 0 & 2 & 4 & 8 & $\mathrm{XI}$ \\
\hline
\end{tabular}

Source: Field Survey, 2009

Note: Final rank order $=||^{*} 3+||^{*} 2+\left.||\right|^{*} 1$

\section{Suggestions for improving broiler farming}

- Good quality day old chicks (DOCs) should be supplied all the year round at fair price.

- Adequate supply of high quality feed at all times at reasonable price.

- Proper veterinary services should be ensured.

- Government intervention for capital supply.

- Ensuring stable market price of broiler meat around the year.

- Effective and skilled training facilities for the broiler farmers.

- Regularity in electricity supply. 


\section{Changes in socio-economic condition}

Seventy two percent broiler farmers informed that their socio-economic condition was improved due to the adoption of broiler farming. On the other hand $28 \%$ respondents implied that their socio-economic condition was remained unchanged (Fig. 3).

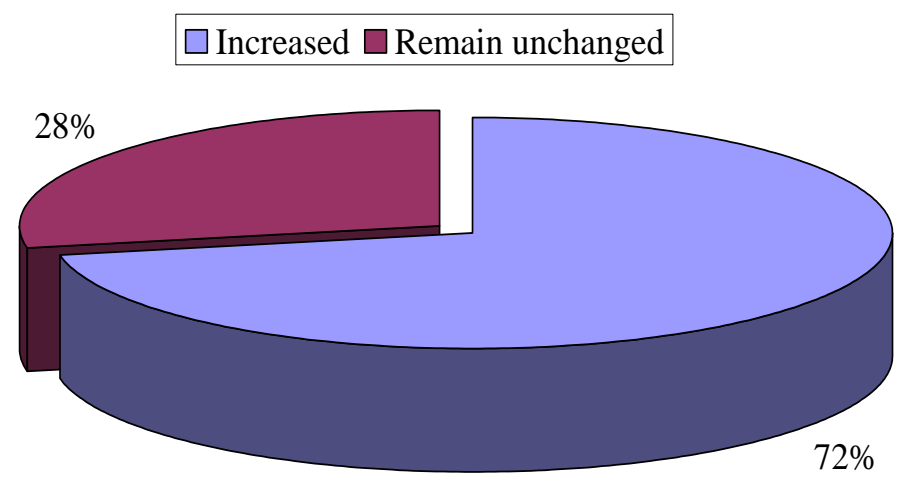

Fig. 3. Change in socio-economic condition of broiler farmers

\section{Conclusion}

Commercial broiler farming in small range created employment opportunities for unemployed family members and generated household income for the adopted farmers. Socio-economic position on subsidiary occupation, monthly household income and expenditure, cash in hand, savings with bank, household assets, number of school going children, monthly consumption of meat, eggs, vegetables, milk and fish, sources of drinking water, condition of latrines and health status of broiler farmers were improved whereas occurrence of diseases annual cost for treatment were reduced after adopting broiler farming. It was observed that commercial broiler farmers faced some problems such as, fluctuation of day old chick and feed prices, high cost of medication \& vaccination and its low quality and high fluctuation of broiler price etc. For removing these problems the respective authorities should have to take necessary steps which were already mentioned in suggestions. Finally, it can be said that small scale broiler farming contributed positively to the socio-economic development of the broiler farmers as well as the improvement of rural livelihood.

\section{References}

Alam, J. 1997. Impact of smallholder livestock development project in some selected areas of rural Bangladesh. Livestock for Rural Development, Vol. 9, No. 3.

Alam, J., Sayeed, M.A., Rahman, S.M.A., Yasmin, F. and Begum, J. 1998. An economic study on poultry farms in Bangladesh. Bangladesh Journal of Livestock Research, 2(1-5).

Barroetoe, A.C. 2007. Nutritive value of poultry meat: relationship between vitamine E and PUFA. World Poultry Science Journal Vol. 63, June 2007

Bhende, M.J. 2006. Production and cost of broiler meat: A case study of Karnataka. Agricultural Development and Rural Transformation Centre. Research Report: 9/ADRT/118, Institute for Social and Economic Change, Bangalore, India, March 2006

DLO. 2008. "Report on poultry", District Livestock Office, Mymensingh: Bangladesh.

Jabbar, M.A., Islam, S.M.F., Ehul, S., Delgado, C., Akanada, M.A.I., Khan, M.I. and Kamruzzaman, M. 2005. Policy and scale factors influencing efficiency in dairy and poultry production in Bangladesh. ILRI (International Livestock Research Institute), Nairobi, Kenya, SLP (Systemwide Livestock Programme), Addis Ababa, Ethiopia) and BSMRAU (Bangabandhu Sheikh Mujibur Rahman Agricultural University), Salna, Gazipur, Bangladesh.

Mulla, N.I. 1995. Marketing of poultry products with special reference to India. Poultry Adviser, 28(8). 
Neumann, C., Harris, D.M. and Rogers, L.M. 2002. Contribution of animal source foods in improving diet quality and function in children in the developing world. Nutrition Research, Volume 22, Number 1, January 2002, pp. 193-220.

Prodhan, S.K. 1995. Broiler farming: A self-employment programme in Tripura, India. Indian farming, pp. 39-41.

Raha, S.K. 2007. "Broiler industry in Bangladesh: some issues", Proceedings of the 5th International Poultry Show and Seminar, March 01-03, 2007. Organized by World's Poultry Science Association, Bangladesh Branch, Dhaka, Bangladesh.

Rahman, S.M.A., Sayeed, M.A., Sarker, N.R. and Alam, J. 2006. Impact of improved poultry management technique on socioeconomic condition of broiler beneficiaries. Journal of Bangladesh Agricultural University, 4 (2): 401-411.

Sirohi, A.S. 1982. Role of dairy and poultry enterprises for increasing income and employment of farmers in the Union Territory of Delhi. Indian Journal of Agricultural Economics, 35(4).

Verma, A.R. and Pillai, A,G.R. 1998. Economics of layer and broiler farming. Poultry Guide, 26 (7). 